\title{
Influence of waste disposal sites on the environment in Miedzyzdoje of $2005-2007$
}

\section{Wpływ składowiska odpadów komunalnych na jakość środowiska naturalnego w Międzyzdrojach w okresie od 2005 do 2007 roku}

\author{
Piotr Daniszewski, Beata Draszawka - Bołzan \\ Katedra Chemii i Ochrony Środowiska Wodnego \\ Wydział Biologii \\ Uniwersytet Szczeciński \\ ul. Felczaka 3C, 71-412 Szczecin, Poland \\ E-mail address: daniszewski@univ.szczecin.pl
}

\begin{abstract}
Waste is inseparable element of human activity. In Poland, the system of it's management is typically extensive because waste is almost entirely deposited in landfills. Landfilling is the oldest method of waste management, but it is also the least desirable method of its neutralization. During the operation of communal waste landfill, waste effects on such environmental elements as air, soil, water, plants and animals. A number of requirements for the location of the facility, its construction, use and handling after operation is supposed to prevent environmental pollution and provide safety for people. The modern waste disposal sites having cleavage in the form of geomembrane, effectively limit the outflow of wastes to the ground waters and neighbouring soils. Further actions which are taken in order to segregate wastes, can eliminate negative effect of waste disposal sites on the environment.
\end{abstract}

Keywords:

waste landfill; communal waste; impact on the environment; water; quality

\section{STRESZCZENIE}

Wytwarzanie odpadów jest nieodłącznym elementem działalności bytowo - gospodarczej człowieka. W Polsce najbardziej rozpowszechniony jest system zarządzania typowo ekstensywny, to dlatego, ponieważ odpady są prawie w całości składowane na składowiskach odpadów. W czasie eksploatacji składowiska odpadów komunalnych oddziałuja one na poszczególne elementy środowiska przyrodniczego tj.: powietrze, glebę, wody, rośliny i zwierzęta. Szereg wymagań dotyczących lokalizacji obiektu, jego budowy, użytkowania oraz postępowania po zakończeniu eksploatacji ma zapobiec zanieczyszczeniu poszczególnych elementów środowiska przyrodniczego oraz zapewnić bezpieczeństwo higieniczno - sanitarne ludziom. Nowoczesne składowiska odpadów posiadające uszczelnienie w postaci geomembrany skutecznie ograniczają odpływ z nich odcieków do wód podziemnych i otaczających gleb. W Polsce należy podejmować dalsze działania w celu segregowania odpadów, które mogą znacznie wyeliminować negatywny wpływ składowisk odpadów na środowisko.

\section{Slowa kluczowe:}

składowisko odpadów, odpady komunalne, oddziaływanie na środowisko, woda, jakość 


\section{WPROWADZENIE}

Zgodnie z Ustawą z 22 stycznia 2010 roku o zmianie ustawy o odpadach oraz niektórych innych ustaw jako odpady komunalne rozumie się „odpady powstajace $w$ gospodarstwach domowych, $z$ wyłaczeniem pojazdów wycofanych $z$ eksploatacji, a także odpady nie zawierajace odpadów niebezpiecznych pochodzace od innych wytwórców odpadów, które ze względu na swój charakter lub skład sa podobne do odpadów powstajacych w gospodarstwach domowych".

Składowiska odpadów i oczyszczalnie ścieków są źródłem emisji wielu związków substancji chemicznych i biologicznych w postaci bioaerozoli, które mogą negatywnie oddziaływać na środowisko naturalne i zdrowie ludzkie [Gonzalez 2000, Hendry 1993, Horner 1995, Daniszewski i in. 2001a, 2001b, Daniszewski 2008, 2009].

Wśród wielu czynników szkodliwych występujących w bioaerozolach na szczególną uwagę zasługują drobnoustroje, które występując w postaci przetrwalników, zarodników, konidii, fragmentów grzybni czy nawet form wegetatywnych (bakterie, wirusy) mogą stwarzać poważne niebezpieczeństwo chorobotwórcze dla zdrowia ludzi, zwierząt i roślin [Barabasz i in. 1998, 2001a, 2001b 2003, Daniszewski i in. 2001a, 2001b, Daniszewski 2008, 2009].

Uwalniany bioaerozol ze składowisk odpadów i oczyszczalni ścieków w wyniku opadania pod wpływem sił grawitacyjnych, gromadzi się na powierzchni gleb, wód, roślin, a także wraz z wodą przemieszczać się może do głębszych warstw gleby, ponadto zawieszony w powietrzu atmosferycznym bioaerozol nie traci swoich właściwości nawet przez długi okres czasu [Barabasz i in. 1998, 2001a, 2001b 2003, Borowski 2001, Borrello i in. 1999, Cronholm 1980, Daniszewski i in. 2001a, 2001b, Gonzalez 2000, Litwin 1977, Mancinelli i in. 1978].

Obiekty komunalne stanowią jedno z potencjalnych źródeł zagrożenia dla człowieka, a wielkość zagrożenia zależy przede wszystkim od charakteru obiektów a także od sposobu ich eksploatacji i aktualnych warunków meteorologicznych i przyrodniczych[Barabasz i in. 1998, 2001a, 2001b 2003, Borowski 2001, Borrello i in. 1999, Cronholm 1980, Daniszewski i in. 2001a, 2001b].

Obiekty komunalne mają wpływ na otaczające gleby, wody powierzchniowe i podziemne, zanieczyszczają atmosferę, a za jej pośrednictwem odległe tereny rolnicze, miejskie i rekreacyjne [Borowski 2001, Daniszewski 2008, 2009, Jagiełło 2003, Jones i in. 1983, Kock i in. 1998].

\section{CZEŚŚĆ DOŚWIADCZALNA}

Składowisko komunalne w Międzyzdrojach zlokalizowane zostało w południowo zachodniej części miasta. Składowisko to było eksploatowane w latach 1948-2002. Międzyzdroje położone są nad Morzem Bałtyckim, na terenie wyspy Wolin. Klimat wyspy Wolin jest różny od klimatu reszty kraju, ponieważ jest silnie kształtowany obecnością Morza Bałtyckiego.

Charakteryzuje go duża wilgotność powietrza, zmienność nasłonecznienia i rozkładu opadów atmosferycznych, siły i kierunku wiatru oraz duże dobowe amplitudy temperatur.

Nieczynne składowisko odpadów komunalnych w Międzyzdrojach o pojemności 250 tys. $\mathrm{m}^{3}$ zajmuje powierzchnię 3,0 ha, $\mathrm{z}$ czego samo składowisko odpadów zajmuje powierzchnię 1,0 ha. Składowisko odpadów w Międzyzdrojach nie zostało w fazie projektowania wyposażone $\mathrm{w}$ drenaż ani też nie zostało uszczelnione. 
Całość wód powierzchniowych (pochodzących zarówno z opadów atmosferycznych jak i ze spływów powierzchniowych) znajdujących się na terenie lub w bezpośrednim sąsiedztwie składowiska odpadów w Międzyzdrojach odprowadzana jest w kierunku południowym, a następnie wschodnim dzięki sieci rowów odbierających te wody. Dalej wody powierzchniowe prowadzone są do cieku Stary Zdrój, który jest dopływem jeziora Wicko Małe.

Również wody podziemne I poziomu wodonośnego (w którym zainstalowano piezometry) drenowane są przez wody Starego Zdroju i jego dopływów. Spowodowane jest to morfologią terenu.

Depresyjny obszar, na którym zlokalizowano składowisko jest hydraulicznie powiązany z płytko zalegającym poziomem wodonośnym i dzięki temu kierunki spływu wód powierzchniowych oraz odpływu wód podziemnych są zbieżne.

Wody infiltrujące z obszaru składowiska nie stanowią zagrożenia dla lokalnych ujęć wody, ponieważ:

1. w najbliższym otoczeniu składowiska nie ma zlokalizowanych aktualnie eksploatowanych ujęć wody służących jako źródło zaopatrzenia ludności w wodę;

2. wody pochodzące $\mathrm{z}$ rejonu składowiska odprowadzane są siecią rowów melioracyjnych do Starego Zdroju, dalej do jeziora Wicko Małe - nie ma więc możliwości głębszej infiltracji wód pochodzących z rejonu składowiska;

3. teren składowiska odpadów znajduje się poza Głównym Zbiornikiem Wód Podziemnych nr 102.

Wyniki badań laboratoryjnych przedstawionych w niniejszym artykule oparto na metodach referencyjnych dla badanych wskaźników jakości wód powierzchniowych i podziemnych zgodnie z załącznikiem nr 4 do Rozporządzenia Ministra Środowiska z dnia 11 lutego 2004 r. w sprawie klasyfikacji dla prezentowania stanu wód powierzchniowych i podziemnych, sposobu prowadzenia monitoringu oraz sposobu interpretacji wyników i prezentacji tych wód.

Powyższe rozporządzenie straciło moc z dniem 1 stycznia 2005 r., w związku z czym podana poniżej klasyfikacja ma charakter pomocniczy.

$\mathrm{Na}$ dzień dzisiejszy nie istnieją obowiązujące akty prawne pozwalające na porównanie otrzymanych wyników badań z wartościami dopuszczalnymi dla poszczególnych wskaźników jakości wody podziemnej.

Badania prowadzone były od 2005 do 2007 roku.

\section{DYSKUSJA WYNIKÓW}

Wyniki badań wód podziemnych i powierzchniowych wraz z klasyfikacją wartości badanych wskaźników wg kryteriów Rozporządzenia Ministra Środowiska z dnia 11 lutego 2004 r. przedstawiono w tabelach nr 1 i 2. 
Tabela 1. Zestawienie wyników badań wód podziemnych wraz z klasyfikacją wartości badanych wskaźników wg kryteriów Rozporządzenia Ministra Środowiska z dnia 11 lutego 2004 r.

- okres badań 2005 - 2007

\begin{tabular}{|c|c|c|}
\hline $\begin{array}{l}\text { Parametry jakości } \\
\text { wód }\end{array}$ & Jednostka & Średnie wartości z punktów pomiarowych \\
\hline pH & - & $\begin{array}{l}\text { od 6,00 [2007rok] - II klasa jakości wód } \\
\text { do 8,5 [2006 rok] - I klasa jakości wód }\end{array}$ \\
\hline $\begin{array}{l}\text { Przewodnictwo } \\
\text { elektryczne } \\
\text { właściwe }\end{array}$ & $\left(\mu \mathrm{Scm}^{-1}\right)$ & $\begin{array}{l}\text { od } 623 \text { (II) [2007rok] - II klasa jakości wód } \\
\text { do } 10500 \text { [2005 rok] - V klasa jakości wód }\end{array}$ \\
\hline $\begin{array}{l}\text { Ogólny węgiel } \\
\text { organiczny (OWO) }\end{array}$ & $\mathrm{mg} \mathrm{C} \cdot \mathrm{dm}^{-3}$ & $\begin{array}{l}\text { od 17,65 [2007rok] - IV klasa jakości wód } \\
\text { do } 3300 \text { [2005 rok] - V klasa jakości wód }\end{array}$ \\
\hline Rtęć & $\mathrm{mg} \mathrm{Hg} \cdot \mathrm{dm}^{-3}$ & $\begin{array}{l}\text { w całym okresie badawczym }<0,0005-\text { I klasa jakości } \\
\text { wód }\end{array}$ \\
\hline
\end{tabular}

Wysoka wartość przewodności elektrolitycznej właściwej jaka kształtowała się przede wszystkim podczas badań w 2005 roku nie jest spowodowana negatywnym oddziaływaniem składowiska odpadów na środowisko gruntowo - wodne. Wysoka wartość tego wskaźnika w wodzie gruntowej, podobnie jak wartości ogólnego węgla organicznego (przede wszystkim w 2005 roku) jest skutkiem naturalnego składu fizykochemicznego wody gruntowej w tym rejonie. Badany obiekt tj. składowisko odpadów w Międzyzdrojach znajduje się na terenie, w którym dominują rowy melioracyjne, zastoiska wody. Dowodzi to obecności płytko zalegającej wody gruntowej, do której w krótkim czasie filtrują wody powierzchniowe pochodzące z opadów atmosferycznych a także ze spływów powierzchniowych. Wraz z tymi wodami filtrują do przypowierzchniowej warstwy wodonośnej związki organiczne naturalnie występujące w przyrodzie, a posiadające w swoim składzie chemicznym węgiel.

Tabela 2. Zestawienie wyników badań wód powierzchniowych wraz z klasyfikacją wartości badanych wskaźników wg kryteriów Rozporządzenia Ministra Środowiska z dnia 11 lutego 2004 r. -

okres badań $2005-2007$

\begin{tabular}{|c|c|c|}
\hline $\begin{array}{l}\text { Parametry jakości } \\
\text { wód }\end{array}$ & Jednostka & Średnie wartości z punktów pomiarowych \\
\hline pH & - & $\begin{array}{l}\text { od 4,96 [2007rok] - V klasa jakości wód } \\
\text { do 9,0 [2006 rok] - II klasa jakości wód }\end{array}$ \\
\hline $\begin{array}{l}\text { Przewodnictwo } \\
\text { elektryczne } \\
\text { wlaściwe }\end{array}$ & $\left(\mu \mathrm{Scm}^{-1}\right)$ & $\begin{array}{c}\text { od } 530 \text { [2007rok] - II klasa jakości wód } \\
\text { do } 43000 \text { [2006 rok] - V klasa jakości wód }\end{array}$ \\
\hline $\begin{array}{l}\text { ogólny węgiel } \\
\text { organiczny (OWO) }\end{array}$ & $\mathrm{mg} \mathrm{C} \cdot \mathrm{dm}^{-3}$ & $\begin{array}{l}\text { od 163,5 [2007rok] - V klasa jakości wód } \\
\text { do } 1100 \text { [2006 rok] - V klasa jakości wód }\end{array}$ \\
\hline Rtęć & $\mathrm{mg} \mathrm{Hg} \cdot \mathrm{dm}^{-3}$ & $\begin{array}{l}\text { w całym okresie badawczym }<0,0005-\text { I klasa jakości } \\
\text { wód }\end{array}$ \\
\hline
\end{tabular}


Podczas badań od 2005 do 2007 roku zaobserwowano w obu punktach pomiarowych podwyższone wartości ogólnego węgla organicznego - ocena tego wskaźnika wg kryteriów Rozporządzenia Ministra Środowiska z dnia 11 lutego 2004 r. klasyfikuje badaną wodę do V klasy jakości. Wysokie stężenia tego wskaźnika związane jest z występowaniem naturalnych związków próchnicznych występujących w warstwie przypowierzchniowej gleby, które w skutek spływu powierzchniowego dostają się do wód powierzchniowych.

W punkcie pomiarowym zlokalizowanym powyżej składowiska odpadów komunalnych w Międzyzdrojach zaobserwowano obniżenie wartości odczynu pH - przede wszystki w 2007 roku.

W 2008 roku zgodne z listą przedsięwzięć priorytetowych przewidzianych do dofinansowania ze środków Wojewódzkiego Funduszu Ochrony Środowiska i Gospodarki Wodnej w Szczecinie w roku 2008 i 2009. Program II - Ochrona litosfery - składowisko odpadów w Międzyzdrojach zostało poddane rekultywacji.

Z informacji uzyskanych w Urzędzie Miasta w Międzyzdrojach wynika, że rekultywacja nieczynnego skałdowiska odpadów będzie kosztowała ponad trzy miliony złotych. Wojewódzki Fundusz Ochrony Środowiska i Gospodarki Wodnej w Szczecinie wsparł finansowo to zadanie udzielając pożyczki w kwocie blisko 2,3 miliona złotych.

Mając na uwadze przytoczone badania w pracy a także aspekt higieniczno - sanitarny nieczynnego składowiska odpadów, tj. narażenie na działanie biologicznych czynników szkodliwych dla zdrowia do których zalicza się: priony, wirusy, bakterie, grzyby, alergeny biologiczne, toksyny biologiczne oraz czynniki rakotwórcze [Barabasz i in. 2003, Borowski 2001, Cvetenić i in. 1997, Rosiek-Dulewska i in. 1996, Smyk 1996], przeprowadzona rekultywacja tego składowiska wpłynie na poprawę poszczególnych elementów środowiska naturalnego.

\section{Podziękowania}

Autorzy artykułu składaja podziękowania Gminie Międzyzdroje ul. Książat Pomorskich 5 za udostepnienie wyników badań składowiska odpadów komunalnych przy ul. Polnej w Międzyzdroje, które zostały wykorzystane do napisania niniejszego artykułu.

\section{Polskie Normy}

PN/C-04540.03. Badania wartości pH, kwasowości i zasadowości. Oznaczanie kwasowości i zasadowości mineralnej i ogólnej metodą miareczkowania wobec wskaźników.

PN/C-04542. Oznaczanie przewodności elektrolitycznej właściwej.

PN/C-04632.03. Ogólne zasady pobierania próbek do badań fizycznych, chemicznych i biologicznych. Technika pobierania próbek.

PN/C-04632.04. Ogólne zasady pobierania próbek do badań fizycznych, chemicznych i biologicznych. Utrwalanie i przechowywanie próbek.

PN/C-06504. Przygotowanie roztworów buforowych. 


\section{References}

[1] Barabasz W., Albińska D., Frączek K., Grzyb J., Barabasz J., Kosińska B., IX Konferencja Naukowo-Techniczna Kołobrzeg-Kopenhaga-Oslo 2003, 155-168, 2003

[2] Barabasz W., Grzyb J., Frączek K., Kultys H., Król T, Flak K., Kornaś G., Barabasz J., Pawlak K., VII Konferncja Naukowo-Techniczna, Koszalin-Kołobrzeg 2001, 157-178, 2001a

[3] Barabasz W., Jaślowska M., Kultys H., Flak K.,Przemiany Środowiska naturalnego a ekorozwój, Wyd. Geosfera TBPŚ, Kraków, 2001, 155-170, 2001b

[4] Barabasz W., Marcinowska K., Bis H., Chmiel M., Galus A., Paśmionka I., Grzyb J., Frączek K., Opalińska-Piskorz J., Pawlak K., Flakowa K., Kornaś G., Kultys H., Król T., /w/ Air Protection in Theory \& Application, PAN, Instytut Podstaw Inżynierii Środowiska, Prace i Studia, 48, III, 145-157, 1998

[5] Borowski S., II Konferencja Naukowa, Łódź-2001, Rozkład i korozja mikrobiologiczna materiałów technicznych. 142-147, 2001.

[6] Borrello P., Gucci P.M., Musmeci L., Pirrera A., Ann. Ist. Super Sanita. 35,3, (1999) 467-471,

[7] Cvetenić Z., Pepeljnjak S.,. Atmospheric Environment. 30(3) (1997) 491-495.

[8] Daniszewski P., Ekologia i technika 5 (2008) 211-214.

[9] Daniszewski P., Gaz, Woda i Technika Sanitarna 4 (2009) 34-36.

[10] Daniszewski P., Falkowski J., Ogólnopolska Konferencja Naukowa - „Problemy higieny i epidemiologii u progu XXI wieku”, Poznań - Kiekrz 2001.

[11] Daniszewski P., Falkowski J. II Ogólnokrajowa Konferencja Naukowa „Rozkład i korozja mikrobiologiczna materiałów technicznych”, Łódź 2001.

[12] Gonzalez C.A., Kogevinas M., Gadea E., Huici A., Bosch A., Papke O., Arch. Environ. Health. 55 (2000) 259-267.

[13] Hendry K. M., Cole E. C., J. Toxicol.Environ. Health. 38(2) (1993) 183-198.

[14] Horner W. E., Helbling A., Salvaggio J. E., Lehrer S. B., Clinical Microbiology Reviews. 8(2) (1995) 161-179.

[15] Jagiełło E., Inżynieria Ekologiczna 9 (2003) 138-144.

[16] Jones B.L., Cookson J.T., Appl. Environ. Microbiol. 45(3) (1983) 919-934.

[17] Jurkiewicz G., Markiewicz P., Skorupski W. Chemia i Inżynieria Ekologiczna. Opole, 5(7) (1998) 583-593.

[18] Kock M., Schlacher R., Pichler-Semmelrock F.P., Reinthaler F.F., Eibel U., Marth E., Friedl H., Cent. Eur. J. Public Health. Austria, 6(1) (1998) 25-28.

[19] Krzysztofik B.: Mikrobiologia powietrza. Oficyna Wydawnicza Politechniki Warszawskiej, Warszawa, 1992.

[20] Krzywicka H., Janowska J., Zarzycka E., Rocz. PZH, 48,3, (1997) 269-274.

[21] Kuratowska A., Rezerwuary chorobotwórczych czynników biologicznych w aerosferze, hydrosferze i litosferze. /w/ Ekologia - jej związki z różnymi dziedzinami wiedzy. PWN, Warszawa-Łódź, 1997.

[22] Litwin B., Człowiek i środowisko 1/4, 1977 
[23] Pleczyński J., Przeglą komunalny 7-8 (1999) 31-33.

[24] Przydatek G., Łacheta S. (2003). Materiały konf. nt. „Mikrozanieczyszczenia w środowisku człowieka”. Wydawnictwo Politechniki Częstochowskiej, str. 588-595.

[25] Rosiek-Dulewska B., Karwaczyńska U., Chemia i Inżynieria Ekologiczna, Opole, 3/5, (1996) 631-634.

[26] Rosik - Dulewska C., Podstawy gospodarki odpadami, Wydawnictwo Naukowe PWN, Warszawa, str. 9-25, 72-85, 331-336, 2008.

[27] Rozporządzenie Ministra Środowiska z dnia 11.02.2004r. w sprawie klasyfikacji dla prezentowania stanu wód powierzchniowych i podziemnych, sposobu prowadzenia monitoringu oraz sposobu interpretacji wyników i prezentacji stanu tych wód.

(Dz. U. Nr 32, poz. 284).

[28] Rozporządzenie Ministra Środowiska z dnia 24 marca 2003r. w sprawie szczegółowych wymagań dotyczących lokalizacji, budowy, eksploatacji i zamknięcia, jakim powinny odpowiadać poszczególne typy składowisk odpadów (Dz. U. Nr 61, poz. 549 - tekst jednolity).

[29] Rozporządzeniu Ministra Środowiska z dnia 9 grudnia 2002r. w sprawie zakresu, czasu, sposobu oraz warunków prowadzenia monitoringu składowisk odpadów (Dz. U. Nr 220, poz. 1858).

[30] Smyk B., Studia Ośrodka Dokumentacji Fizjograficznej, PAN Kraków, 24, (1996) 113-144.

[31] Strączyńska., Strączyński S., Zesz. Probl. Post. Nauk Roln. 471 (2000) 543-548.

[32] Struk-Sokołowska J., Żebranowicz E., Wiater J., Journal of Elementology. T.10(3) (2005) 821-828.

[33] Szymańska-Pulikowska A., Zesz. Probl. Post. Nauk Roln. 471 (2000) 1175-1179.

[34] Szymański K. III Międzynarodowe Forum Gospodarki Odpadami. Techniczne i społeczne aspekty gospodarki odpadami, Poznań, (1999) str. 425-444.

[35] Terelak H., Motowicka - Terelak T., Stuczyński T., Pietruch C., Inspekcja Ochrony Środowiska, Warszawa, str. 5-7, 16-50. (2000).

[36] Ustawa z dnia 27 kwietnia 2001r. o odpadach (Dz.U. 2001.62. poz. 628). 